\title{
The Development of Audio-Based Pop-Up Book Media on Two-Dimensional Rectangular For Junior High School Students
}

\author{
Lufita Elfiani, Marhan Taufik, Baiduri
}

\author{
Study Program of Mathematics Education \\ Faculty of Teacher Training and Education \\ University of Muhammadiyah Malang \\ lufitaelfiani65@gmail.com
}

\begin{abstract}
This study aimed to develop the learning media and investigated the effectiveness of audio-based Pop-Up Book media on the two-dimensional rectangular shape. This media was tested twice in a small group of 6 students and in a large group of 25 students. Respondents were the VII ${ }^{\text {th }}$ grade students. The result of expert validation showed the average percentage of $88,16 \%$ and was considered valid, thus the learning media was allowed to be used and tested. The analysis of effectiveness in small and large groups in a row revealed that students' respond was very good, with the percentage of $88.1 \%$ and $88.87 \%$. In addition, the activities of students in the class were very good, showed by the percentage of $92 \%$ and $86.8 \%$. Finally, the classical completeness of the learning outcomes obtained the percentage of $100 \%$ from 6 students and $92 \%$ from 23 students who completed the test. Therefore, it can be concluded that the application of audiobased Pop-Up Book on the two-dimensional rectangular shape was effective for Junior High School students.
\end{abstract}

Keywords: Learning media, Pop-Up, Audio, 2D Rectangular.

\section{INTRODUCTION}

Mathematics is one lesson that plays an important role in the development of science. Mathematics is available at the elementary school level up to the tertiary level (PT). Indonesia in the 2015 Program for International Students Assessment (PISA) reported that Indonesia was ranked 63 out of 70 countries for mathematics with a score of 386. PISA stated that Indonesia was still relatively low in mastering the material. At present students' interest in mathematics is still lacking, the factor is due to long lesson hours, many formulas, and difficult to understand, for students the formula in abstract mathematics and difficult to solve (Pamuji, Budiyono \& Yuzianah, 2014). Students who consider mathematics to be a relatively difficult subject and form negative impressions and experiences of mathematics generally have a bad impact on motivation to learn mathematics (Gurganus, 2010).

This means that there is a need to develop a mathematical learning process by utilizing existing technological developments, namely presenting a learning media of mathematics to help students make it easier to understand concepts, solve problems and can facilitate the achievement of the objectives of mathematics learning. Learning media is a container to convey learning messages so that learning objectives can be achieved. Creative use of media can increase the possibility for students to learn more, remember well (Riyana, 2012). Learning media can visualize mathematical material that tends to be abstract (Widodo \& Wahyudi, 2018). Learning media are used to facilitate communication in the teaching and learning process, optimally sought to be able to foster creativity and motivation in learning activities to improve the quality of education (Wiana, 2017).

One type of learning media that can make students interested, not bored, and help students during the learning process is Pop-Up media. Pop-Up is amazing when used in learning activities in the form of visual media. Media Pop-Up visuals can provide a very interesting 
visualization of stories because the images presented can move in any part that is opened or shifted, and the appearance is in the form of two and three dimensions (Widalatika, 2014). PopUps contain pieces of paper that appear or move when they are opened and fully folded when the book is closed, and the appearance is in the form of two or three dimensions (Ahmadi, Fakhruddin, Trimurtini \& Khasanah, 2017). Media Pop-Up is a folded piece of paper where a two-dimensional or three-dimensional structure appears when opened (Okamura \& Igarashi, 2010).

Several studies relevant to the development of Pop-Up Book as a media for learning mathematics are Kharisma (2017) developing Pop-Up learning media to improve student learning outcomes in petroleum and petrochemical materials. Dewanti (2018) developed the Pop-Up Book media for learning the environment in which I live. Shita \& Maisaroh (2017) developed the Pop-Up puppet pandhawa character book. Azizan (2017) developed a Pop-Up Book in learning Psychowriting based poetry writing. Vate (2012) developed the 3D Augmented Reality Multimedia Pop-Up Book media in English lessons. The four studies that are relevant to developing the Pop-Up Book media as learning media.

The development of Pop-Up learning media developed this time, added audio to make it more interesting and more interactive, and students are more excited when learning takes place. The information presented will give a deep and longer impression stored on students and can increase the attention of each student. Through audio-visual media, learning content can be more interactive and allow two-way traffic in the learning process (Haryoko, 2012). Silent audio-visual media is a medium whose delivery of messages can be received by hearing and sight, but images that are presented as still or slightly motionless (Susilana \& Riyana, 2009). Audio-visual media is a combination of images and sounds to actualize or visualize certain realities based on images (Cintas \& Remael, 2014).

Through the development of audio-based Pop-Up learning media, students are expected to be easier to understand mathematics lessons and attract interest in learning especially in quadrilateral flat building material. The rectangular flat builds described in this media are square, rectangular, lengthy, trapezoidal, kite and rhombus. With the existence of audio-based Pop Up media, it is hoped that it can help to provide solutions related to rectangular flat building Quadrilateral (rectangular, square, length, divide, kite, and trapezoidal) material is very important to be mastered by class VII students because it becomes a prerequisite material when students sit in class VIII learn to build flat side spaces (Mustakim, 2016). Quadrilateral flat material is a prerequisite material for studying material in the form of flat side space and congruence (Rahayu, 2016).

The relationship between research that is relevant to current research is to produce audio-based Pop-Up Book learning media on quadrilateral flat build material. The development of audio-based Pop-Up Book media is assessed based on validity which includes 5 aspects, namely: 1) aspects of appearance, 2) aspects of audio, 3) aspects of language, 4) aspects of layout and 5) aspects of content. In addition, the development of audio-based Pop-Up Book media looks at student responses, student activities, and student learning outcomes after using audio-based Pop-Up Book media. The development of audio-based Pop-Up Book media aims to describe the process of developing and effectiveness of audio-based Pop-Up Book learning media.

Not all learning media are effectively used during learning activities. Learning media is said to be effective if the student response questionnaire is good with a percentage of $\geq 75 \%$, good student activity with a percentage of $\geq 75 \%$ and student learning outcomes complete if the score above KKM is 75 with the percentage of classical completeness $\geq 75 \%$ 
(Wahyuningsih, 2012). Media that is said to be effective if it can increase student interest in learning and the achievement of learning goals (Musfiqon, 2012).

\section{RESEARCH METHOD}

This research was research and development $(\mathrm{R} \& \mathrm{D})$ research using a Sugiyono model which has ten stages, namely potential problems, information gathering, product design, design validation, design revision, product testing, product revision, usage testing, product revisions, mass production. In this study, the researchers only conducted until the ninth stage. This research was conducted in the odd semester of the 2018/2019 academic year. The trial was conducted at Ma'arif 03 Malang Islamic High School with the subject of class VII students.

The research procedure used in accordance to stages the development Sugiyono model. a) Stage of potential problems related to problems found at school regarding the use of instructional media used. b) The stage of information gathering was done by interviewing teachers in the field of mathematics. c) The product design phase, which starts from the preparation of the material, compiling the cover, packaging box, contents of the Pop-Up Book, the audio-based Pop-Up Book guidance, dubbing, and installation of audio and planning the materials used to print Pop-Up Book and audio installation. d) Design Validation Phase, which required some experts or experts who are experienced to assess the newly designed product, namely the expert validator was a lecturer in mathematics education and learning practitioner who is a teacher. e) The design revision stage, namely the shortcomings provided by the validator were tried to be reduced by improving the design. The product trial stage was carried out in small groups of 6 students. f) The product revision stage, namely the shortcomings obtained in the product trial try to be repaired. g) The trial phase was carried out in a large group of 25 students. h) Product revision stage, that is, if there was still a shortage in the last trial researchers need to improve.

1. Data collection instruments used the validation sheet of media, student response questionnaire, a student activity sheet and learning outcome test. The media validation questionnaire used to measure the level of validity of the media. Student questionnaire responses, student activity sheets, and learning outcome test sheets used to determine the effectiveness of media products. The following aspects assessed in the development of audio-based Pop-Up Book media: Media validation consisted of 5 aspects, each of which has indicators (Hermanto, 2015). a) display aspects: composition and layout on a balanced cover, full pop-up color appearance, letters used clear and easy to read, illustrated images and material were easy to understand, image quality is clear. b) audio aspects: the voice of the narrator sounds clear, the questions conveyed were easy to understand and clear. c) aspects of language: use Indonesian language that was good and correct, language was easily understood by students. d) layout aspects: layouts were not monotonous, layouts were easy to use, the accuracy of images and material. e) aspects of the content: the accuracy of the title with the content of the material, the clear description of the material, the presentation of the material was easy to understand, the sample questions given were clear.

2. Student responses consist of 3 aspects, each of which has indicators (Anggi \& Dede, 2014). a) aspects of content: using good and correct language, material easy to understand and clear, examples of questions given are clear. b) display aspects: each page was interesting, the image presented was clear, the layout was not boring, it looks colorful full, interesting writing models. c) audio aspects: sounds can be heard clearly, the questions conveyed are easy to understand. 
3. Student activities consisted of 5 aspects, each of which has indicators (Sardiman, 2011). a) visual aspect: using a pop-up book, the layout clearly visible, the image presented is clear, interested in learning media. b) listening aspect: students listened to the sound clearly, easily understand the questions conveyed, easily use the audio player. c) aspects of writing: recording the results obtained in learning, writing down the questions correctly received. d) drawing aspect: depicting the flat building that has been studied, illustrates the problem that was conveyed through the audio player. e) emotional aspects: love to take part in audiobased pop-up book learning, dare to ask the teacher. f) mental aspects: preparing for learning, paying attention to teacher's direction, enthusiasm for learning.

4. Student learning outcomes, The test used to determine student learning outcomes after using audio-based Pop-Up Book learning media. The test in the form of four items given separately from the audio-based Pop-Up Book analyzed in accordance with the Minimum Completion Criteria (KKM) used at Ma'arif 03 Islamic High School in Malang.

Data analysis techniques include validity analysis and effectiveness analysis. The product was said to be valid with a percentage of $\geq 60 \%$. Validity data analysis obtained by calculating the validity percentage by dividing the number of scores obtained with the maximum score from the validator in each aspect and multiplied by $100 \%$.

\section{RESULT AND DISCUSSION}

The steps used in developing this product adopt and adapt the development process of Sugiyono which consists of nine stages, namely potential problems, information collection, product design, design validation, design revisions, product trials, product revisions, product usage, and product revisions. The activities of each stage in the product development process are as follows:

\section{Potential Problems}

The results obtained during the learning activities, the teacher uses the lecture method with the help of textbooks and LKS. Students also feel bored with such repeated learning activities. The use of learning media in schools is very minimal. As well as facilities such as LCDs are also still not available in every class. If the teacher uses PowerPoint media usually see the class situation first because the availability of LCD is only available in the Laboratory. So based on the above problems it is necessary to have new learning media in the form of Audio-based Pop-Up Book for students so that students do not get bored when learning activities take place. Learning media developed about the properties, extent, and circumference of a flat quadrilateral.

\section{Information Collection}

The researcher made observations and interviews directly to the school. This preliminary study includes observations when learning activities take place and interviews students and mathematics teachers regarding the media used during learning mathematics. The media developed must be in accordance with Basic Competencies (KD) and indicators that have been formulated. Formulating Basic Competencies (KD) is understanding the properties of flat building and using them to determine circumference and area, solving real problems related to the application of the properties of rectangles, squares, trapezoidal, square, rhombus, and kites. Formulating indicators that are knowing the types of flat rectangular shapes and their properties, solving problems related to rectangular flat builds. 


\section{Product Design}

The product design phase needs the help of Corel Draw X7 software. This program is used to design the Pop-Up Book before it will be printed.

a. Preparation of Material, namely quadrilateral flat using the Mathematics book of SMP / MTS class VII in the second semester of the 2013 curriculum revised edition 2017.

b. The arrangement of Cover, which is a front and back cover made on worksheet A3 Corel Draw X7 software. The paper used for printing is Art Paper with a thickness of 150 grams with A2 size. So the cover design is placed in the middle of the A2 paper so that it has the remainder at the bottom and right left. After printing, on the back side of the middle part is affixed A3 size paperboard with a thickness of $4.3 \mathrm{~mm}$ then the remaining paper top and bottom left are also taped to the cardboard.

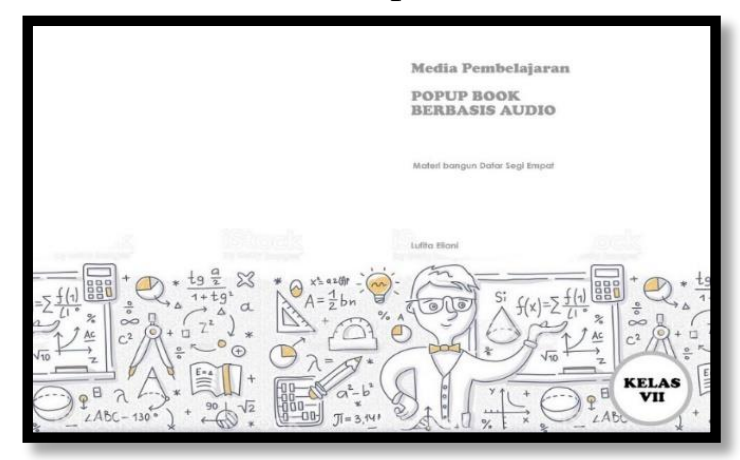

Picture 1: Cover Display

c. The preparation of the Packaging Box, which is made by the worksheet of Corel Draw $\mathrm{X} 7$ software with a size of $61 \mathrm{~cm} \times 54 \mathrm{~cm}$. Printed using Art Paper paper with a thickness of 310 grams measuring $70 \mathrm{~cm} \times 60 \mathrm{~cm}$.

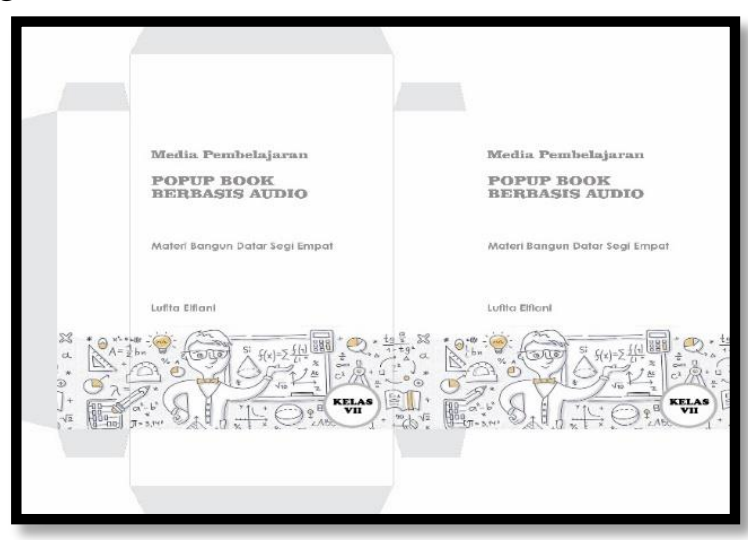

Picture 2: Packaging Display

d. Preparation of Pop-Up Book Contents, namely the contents of the Pop-Up Book, is made on the worksheet of the A3 size Corel Draw X7 software. In the content section, there are $\mathrm{KD}$, indicators, table of contents, audio, properties of a flat quadrilateral, broad formulas and circumference of flat square shapes, examples of rectangular flat builds and examples of rectangular flat builds. Printed using Art Paper paper with a thickness of 310 grams. 


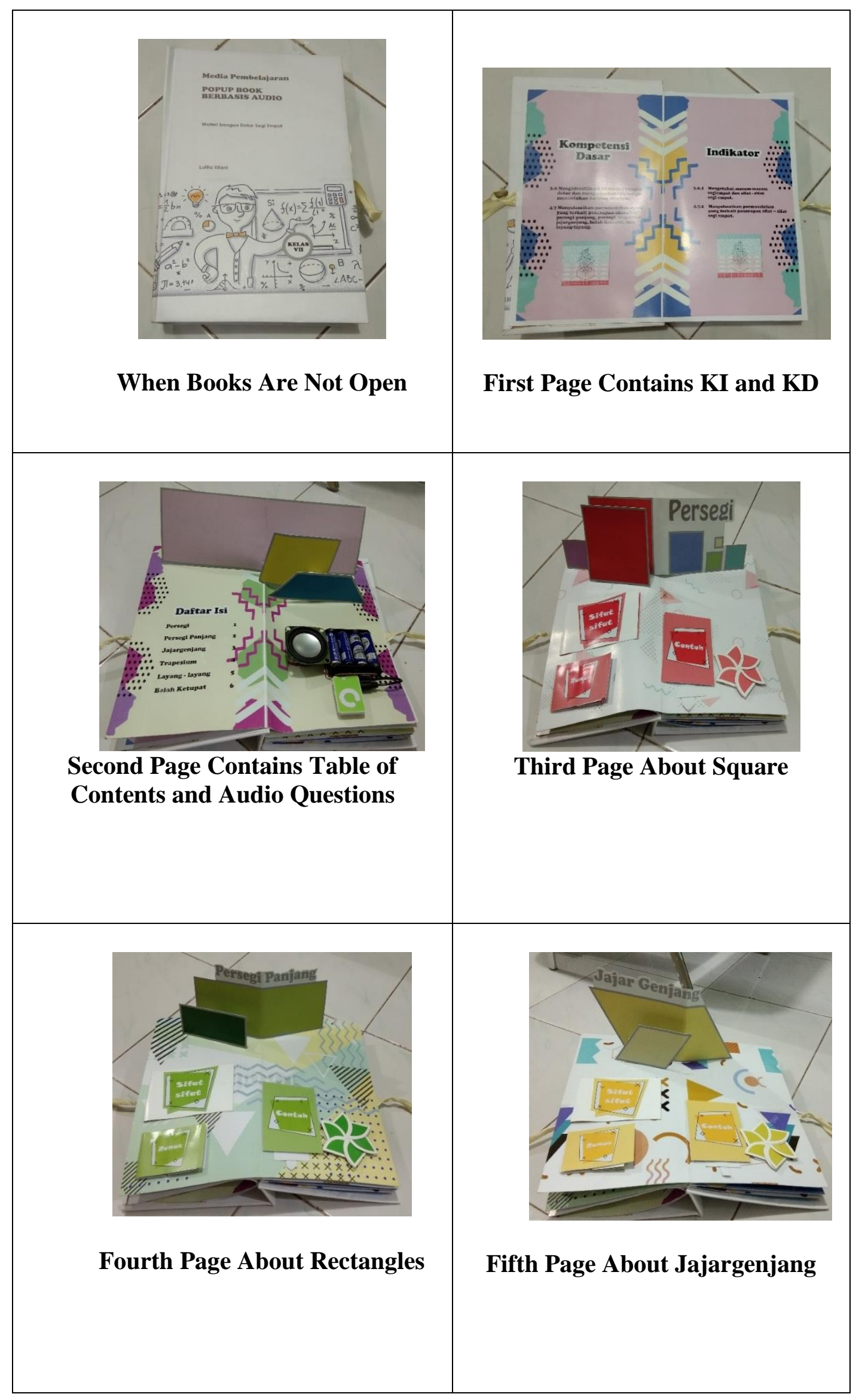




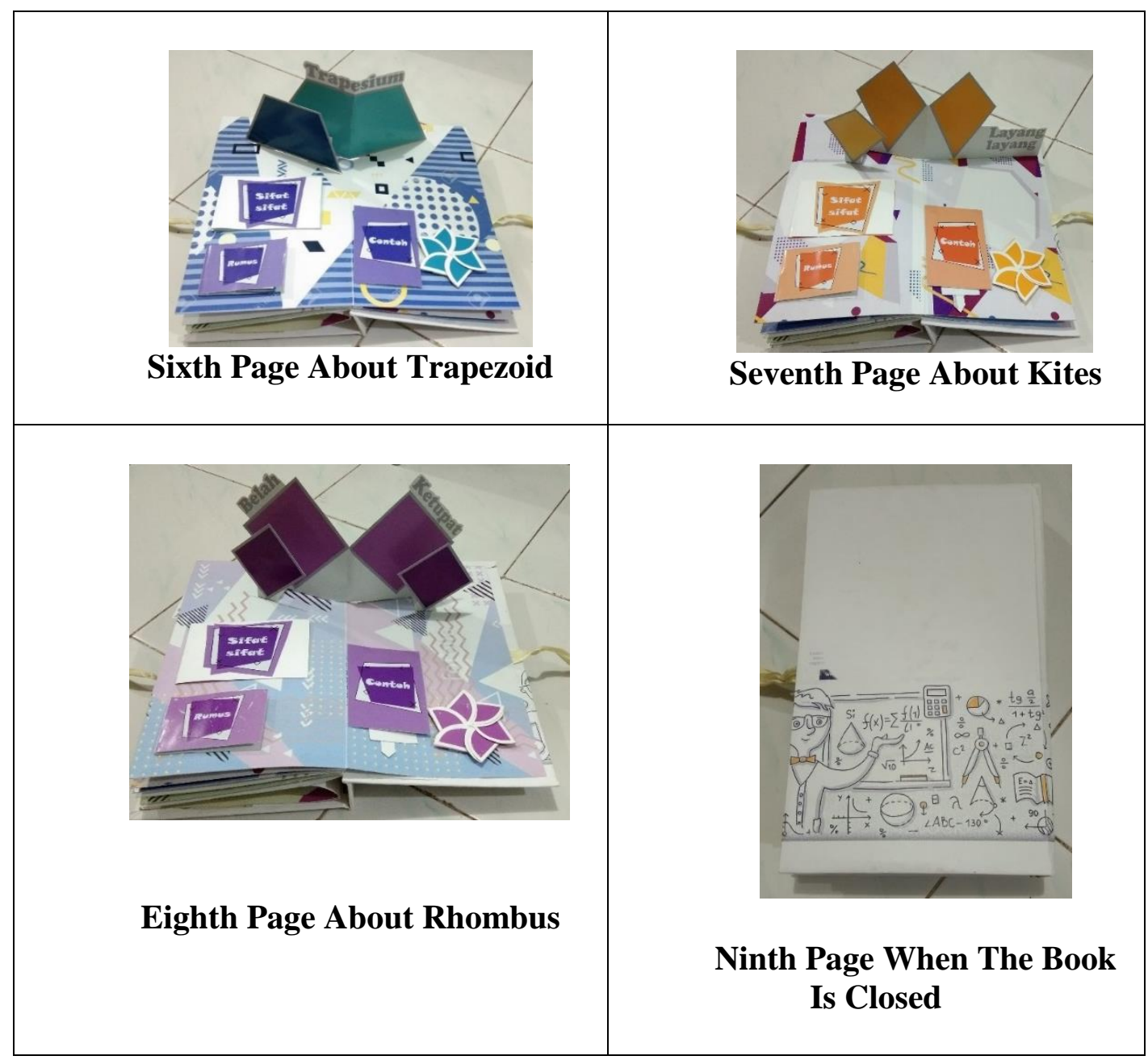

Picture 3: Fill in the Pop-Up Book

e. The audio-based Pop-Up Book guidance are made on the A5 size Corel Draw X7 software worksheet and printed back and forth using Paper Art paper with a thickness of 150 grams.
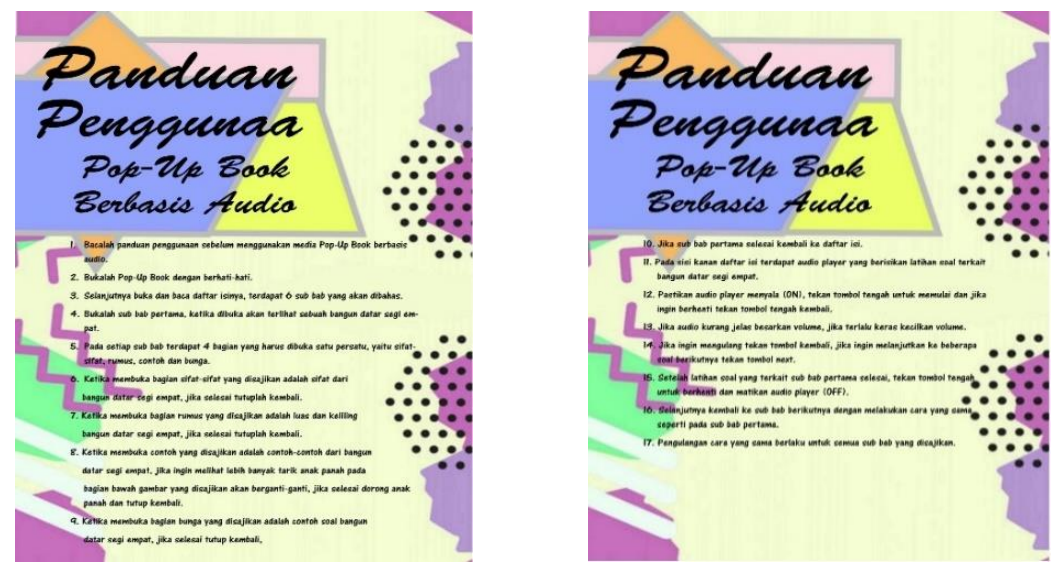

Picture 4 : The Audio-Based Pop-Up Book Guidance 
f. Dubbing preparation is to record the questions submitted, researchers are assisted with the application "Voice Changer". The questions were 30 questions consisting of 5 square questions, 5 rectangular questions, 5 long question questions, 5 trapezoid questions, 5 kite questions and 5 rhombus questions.

g. The audio compilation is affixed to the second page besides the list of contents needed for composing audio is the speaker with a ratio of $65 \mathrm{~dB}, \mathrm{mp} 3$, memory, battery box, 4 batteries with AA LR6 1.5V size, cables, alternating black solutions.

\section{Design Validation}

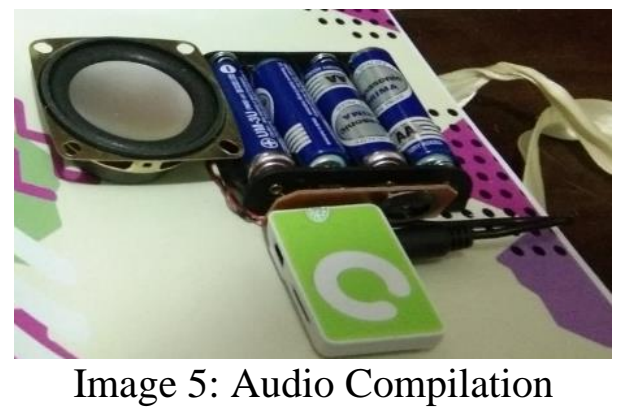

Audio-based Pop-Up Book learning media on flat-build material in junior high school validated by 2 validators. The two validators, the expert validator is a lecturer in Mathematics Education at the University of Muhammadiyah Malang and a learning practitioner is a seventh-grade mathematics teacher at Ma'arif 03 Islamic Junior High School Malang. The results of the assessment by the two validators, namely the display aspect obtained an average percentage of $95 \%, 81.25 \%$ audio aspects, language aspects $87.5 \%, 83.3 \%$ aspect layout and $93.75 \%$ content aspects. Of the four aspects, the average value of $88.16 \%$ is very valid with information worthy of use. With some suggestions given by the validator for improvement.

5. Design Revision

After entering the validation phase there are several revisions that have been submitted by the validator through the comments and suggestions column that is available in the sheet of media validation. Error writing "Usera" which should be "Usage". Layout errors, for example, the flat wake that is presented, should wake up with a description of the sides, base, height and so on put on the front.

6. Product Testing

Audio-based Pop-Up Book that has been validated and repaired and declared feasible by media experts and practitioners and then tested it on class 7 students of Ma'arif Islamic Middle School. This product trial was carried out by 6 class VII students and randomly selected, namely 3 female students and 3 male students. Audio-based Pop-Up Book given to small groups of 6 students. During the media trial, an observer assessed the activities of students using the media. Every time students are asked to do the exercises in the audio questions in groups, after that they are corrected together. At the end of the lesson, students are given a test and response questionnaire.

The results obtained in this product trial are the activity of students having an average percentage of $92 \%$ with very good criteria, student questionnaire responses having an average percentage of $88.1 \%$ with very good criteria and for student learning outcomes having an average the percentage of classical completeness is $100 \%$ with KKM 75.

7. Product Revision 
It is necessary to use an additional speaker ratio of $100 \mathrm{~dB}$ in order to harden the audio problems if tested in large groups. Many received positive comments about audiobased Pop-Up Book media.

8. Usage Trial

Audio-based Pop-Up Book that has been validated and repaired and declared feasible by media experts and practitioners and then tested it on class 7 students of Ma'arif Islamic Middle School. This usage trial was conducted by 25 class VII students. Audio-based PopUp Book given to each group of 5 students. During the media trial, an observer assessed the activities of students using the media. Every time students are asked to do the exercises in the audio questions in groups, after that they are corrected together. At the end of the lesson, students are given a test and response questionnaire. The results obtained in this product trial are the activity of students having an average percentage of $86.8 \%$ with very good criteria, student response questionnaires have an average percentage of $88.87 \%$ with very good criteria and for student learning outcomes to have average data percentage of 92\% classical completeness with KKM 75.

9. Product Revision

There was no revision after a large group usage trial was conducted on class VII students, amounting to 25 students at Ma'arif 03 Islamic Junior High School Malang.

\section{Discussion}

Based on the results of the research that has been done, audio-based Pop-Up Book learning media on quadrilateral flat material in junior high school has been developed in accordance with nine stages, namely potential problems, information gathering, product design, design validation, design revision, product testing, product revision, trial usage, product revision. The validity of the media is assessed based on the data analysis of the media validation sheet, in which there are display aspects, audio aspects, language aspects, layout aspects, and content aspects. The results of the audio-based Pop-Up Book learning media validation are very valid, so audio-based Pop-Up Book media is feasible to be tested in learning quadrilateral flat builds.

Learning media that have been created and have been validated are then tested to see their effectiveness by conducting 2 trials on class VII students. The first is the student response questionnaire which is assessed based on the aspects of the content, appearance aspects, and audio aspects. The results of data analysis of student responses in trial 1 and trial 2 were stated to be very good. Second is the activity of students who are assessed based on the visual aspects, aspects of writing, aspects of drawing, emotional aspects and mental aspects. The results of the analysis of student activity data in trial 1 and trial 2 were stated to be very good. Third, student learning outcomes that are assessed based on the questions given after using audio-based PopUp Book media must meet the minimum completeness criteria (KKM), namely 75 . The results of the analysis of the percentage of classical completeness of students in trial 1 and trial 2 are expressed as $75 \%$. It can be concluded that the audio-based Pop-Up Book media is said to be effectively used as a learning media in quadrilateral flat building material.

This is in line with the research (Dewanti, 2018) and (Safri, Sari \& Marlina, 2017) stating the feasibility of media seen from the results of overall validation, namely $95.20 \%$ and $92.67 \%$ with very valid criteria, then the media is feasible to be used in learning. (Azizan, 2017) and (Kharisma, 2017) state the results of questionnaire questionnaires, student activities and learning outcomes in a row. Questionnaire responses that have an average percentage of $98 \%$ and $92 \%$ with very good categories, student activities in the class have an average percentage of $88.8 \%$ and $97 \%$ with very good categories while student learning outcomes have an average percentage of classical completeness of $82 \%$ and $87 \%$ with very good categories. Which means 
that the effective Pop-Up Book media is used as a learning media. (Vate, 2012) conducted 2 trials by giving a test, the first test gained $87.78 \%$ and the second test gained $87.4 \%$.

\section{CONCLUSION}

The conclusions of this study are (1) The process of developing audio-based Pop-Up Book media on quadrilateral flat waking material through 9 stages. The stages of making audio-based Pop-Up Book, namely potential problems, information gathering, design, media validation, media revisions, media trials, media revisions, media usage trials, and media revisions. In making it aided by Corel Draw X7 software. The results of the validation obtained from the media expert validator and learning practitioner the average percentage is $88.16 \%$ with very valid criteria, which means that audio-based Pop-Up Book media is worthy of being used as a learning medium in quadrilateral flat building material. (2) The effectiveness of the media seen from the minimum student response questionnaire has good criteria, while the minimum student activity has good criteria and minimum learning outcomes have a percentage of classical completeness $\geq 75 \%$. Student responses to audio-based Pop-Up Book learning media have a very good response. While the activities of students when learning using audio-based Pop-Up Book learning media have very good activity. And student learning outcomes after using audiobased Pop-Up Book learning media obtain a percentage of classical completeness $\geq 75 \%$. From the results of student questionnaire responses, student activities and learning outcomes that have been tested showed the results that the audio-based Pop-Up Book media in quadrilateral flat material in SMP was effectively used as a learning media.

\section{REFERENCES}

Ahmadi, farid., Fakhruddin., Trimurti., \& Khasanah Khafidhotul. 2017. The Development Of Pop-Up Book Media To Improve 4th Grade Students' Learning Outcomes Of Civic Education. Universitas Negeri Semarang. 3rd International Conference On Theory \& Practice. 978-0-9953980-5-4.

Arikunto, Suharsimi. 2013. Prosedur Penelitian : Suatu Pendekatan Praktik. Jakarta: PT. Rineka Cipta.

Azizan, Yoga. 2017. Pengembangan Pop Up Book Dalam Pembelajaran Menulis Puisi Berbasis Psychowriting Pada Siswa Kelas VIII D SMP Negeri 1 Srengat Kabupaten Blitar. Surabaya : Universitas Negeri Surabaya.

Cahyadi, Dede. 2014. Pengembangan Media Pembelajaran Berbasis Flash Pada Mata Pelajaran IPA Terpadu Pokok Bahasan Wujud Zat Dan Perubahannya Kelas VII SMPN 5 Satu Atap Bumijawa. Semarang : Universitas Negeri Semarang.

Cintas, Jorge Diaz., Remael, Aline. 2014. Audio-Visual Translation. SysMedia. WinCaps : Routledge

Dewanti, Handaruni. 2018. Pengembangan Media Pop Up Book Untuk Pembelajaran Lingkungan Tempat Tinggalku Kelas IV SDN 1 Pakunden Kabupaten Ponorogo. Malang : Universitas Negeri Malang.

Djijar, Canggih Devi. 2015. Efektifitas Media Pop-Up Book dalam meningkatkan kemampuan membaca cerita mata pelajaran bahasa Indonesia kelas I sekolah dasar Brawijaya smart school malang. Malang : Universitas Negeri Maulana Malik Ibrahim.

Gurganus. 2010. Characteristics of student's mathematics learning. www.education.com/reference/article/students- math-learning-problems/. 
Haryoko, Sapto. 2009. Efektifitas Pemanfaatan Media Audio-Visual Sebagai Alternatif Optimalisasi Model Pembelajaran. Makasar. Universitas Negeri Makasar. Jurnal Edukasi Elektro

Kharisma, Miftahul. 2017. Pengembangan Media Pembelajaran Pop Up Book Untuk Meningkatkan Hasil Belajar Siswa Pada Materi Minyak Bumi Dan Petrokimia Di Kelas XI MAS MUTA'ALLIMIN Aceh Besar. Banda Aceh : Universitas Islam Negeri ARRanry.

Musfiqon. 2012. Pengembangan Media \& Sumber Pembelajaran. Jakarta : PT. Prestasi Pustakaraya

Okamura, Sosuke., Igarashi, Takeo. 2010. An Assistant Interface to Design and Produce a PopUp Card. Japan : University of Tokyo. International Journal of Creative Interfaces and Computer, 1(2), 40-50.

Pamuji, Tri, dkk. 2014. Persepsi Terhadap Mata Pelajaran Matematika Siswa SMP Kelas VIII. Purworejo : Universitas Muhammadiyah Purworejo.

Rahayu, S. 2016. Analisis Kesalahan Siswa dalam Menyelesaikan Soal-soal Kesebangunan. Jurnal e-DuMath, 2(1): 1-9.

Riyana, Cepi. 2012. Media Pembelajaran. Jakarta : Direktorat Jendral Pendidikan Islam, Kementrian Agama RI.

Safri, Meilia., Sari, Sri Adelia., Marlina. 2017. Pengembangan Media Belajar Pop-Up Book Pada Materi Minyak Bumi. Jurnal Pendidikan Sains Indonesia, Vol. 05, No.01, hlm 107-113.

Shita, Anggit \& Siti Maisaroh. 2017. Pengembangan Buku Pop-Up Wayang Tokoh Pandhawa Pada Mata Pelajaran Bahasa Jawa Kelas V SD. Yogyakarta : Universitas PGRI Yogyakarta.

Sugiyono. 2015. Metode Penelitian : Kuantitatif, Kualitatif, dan R\&D. Bandung : Alfabeta.

Susilana, Rudi \& Cepi Riyana. 2009. Media Pembelajaran. Bandung : CV. Wacana Prima.

Vate, Poonsri. 2012. An Augmented Reality 3D Pop-Up Book: the Development of a Multimedia Project for English Language Teaching. Bangkok : Assumption University of Thailand.

Wiana, W. 2017. Inetrractive Multimedia-Based Animation : A Study Of Effectiveness On Fashion Design Technology Learning. Bandung : Indonesia University of Education. The 2nd International Joint Conference on Science and Technology (IJCST).

Widalatika, Vladina Nur. 2014. Pengembangan Media Visual Kirigami Pop Up Dengan Materi Potensi Dan Sebaran Sumber Daya Alam Indonesia Untuk Pembelajaran IPS Di SMP Kelas VII. Yogyakarta : Universitas Negeri Yogyakarta.

Widodo, S. A., \& Wahyudi. (2018). Selection of Learning Media Mathematics for Junior School Students. TOJET (The Turkish Online Journal of Educational Technology),17(1), 154-160.

Wirayanti, P.M., Hidayah, I.N., \& Muksar, M. 2016. Pengembangan Lembar Kegiatan Siswa (LKS) Dengan Strategi REACT Pada Materi Keliling Dan Luas Lingkaran. Pendidikan Matematika UNISSULA 